\title{
The effects of traffic accidents on pregnancy: Is hospitalization necessary in every case?
}

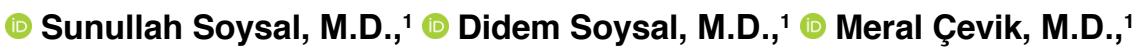

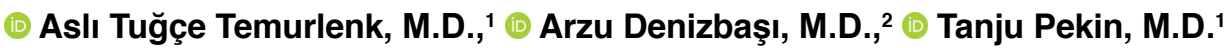

${ }^{1}$ Department of Obstetrics And Gynecology, Marmara University İstanbul Pendik Training and Research Hospital, İstanbul-Turkey
${ }^{2}$ Department of Emergency Medicine, Marmara University İstanbul Pendik Training and Research Hospital, İstanbul-Turkey

\begin{abstract}
BACKGROUND: This study aimed to show whether it is necessary to hospitalize pregnant women who have been involved in traffic accidents.

METHODS: Patients at a hospital in Istanbul, Turkey, who underwent traffic accidents between 2012 and 2018 were studied, and pregnant patients' files were evaluated. Demographic and obstetric features of patients, type of accident, type of trauma, Glasgow Coma Score, whether or not hospitalization were examined, the response of patients to hospitalization, and the obstetric and maternal results of accidents were assessed.
\end{abstract}

RESULTS: In the present study, 95 patients were included. Overall, hospitalization was recommended for 50 patients, but of these, $58 \%$ refused to be admitted. No patients who refused hospitalization had complications. Preterm labor was seen in $3.2 \%$ of patients, while $3.2 \%$ had a fetal loss and $5.3 \%$ had a placental abruption. Only one mother was lost (I.I\%) due to sustaining multiple traumas in a traffic accident. Hospitalization was increasingly indicated with increasing gestational age, but other parameters had no effect on hospitalization.

CONCLUSION: The likelihood that hospitalization was recommended for pregnant women involved in traffic accidents increased with gestational age. Patients with minor trauma who refused hospitalization had no complications.

Keywords: Hospitalization; pregnancy; traffic accidents.

\section{INTRODUCTION}

Traffic accidents affect people of all age groups. It was reported that I,313,359 traffic accidents occurred in Turkey in 2015. In these accidents, 383I patients died in accident time and 3699 patients died on follow-up. ${ }^{[1]}$ Overall, it seems that $8 \%$ of pregnancies are complicated by trauma, ${ }^{[2,3]}$ which is the leading non-obstetric cause of maternal death. ${ }^{[4]} \mathrm{Al}$ though the incidence of traffic accidents during pregnancy in Turkey is not known, the event rate of traffic accidents during pregnancy was 6.47 per 1000 cases in Canada. ${ }^{[5]}$ The risk of stillbirth, preterm labor, uterine rupture, cesarean section, placental abruption, spontaneous abortion, and preterm premature rupture of membranes increases with trauma during pregnancy. ${ }^{[6-10]}$ It has been shown that the fetal death rate due to maternal trauma was 2.3 per 100,000 live births. ${ }^{[1]}$ Placental abruption was the major factor leading to fetal death. ${ }^{[12]}$

It is recommended that every injured female of childbearing years should be checked for a possible pregnancy. Following admission of the patient for further care in a healthcare facility, a pregnancy test should be performed. The confirmation of pregnancy may have a major impact on future decisions regarding diagnostic imaging, use of medications, and other treatment modalities. ${ }^{[13]}$

Cite this article as: Soysal S, Soysal D, Çevik M, Temurlenk AT, Denizbaşı A, Pekin T. The effects of traffic accidents on pregnancy: Is hospitalization necessary in every case? Ulus Travma Acil Cerrahi Derg 2021;27:73-78.

Address for correspondence: Sunullah Soysal, M.D.

Marmara Üniversitesi İstanbul Pendik Eğitim ve Araştırma Hastanesi, Kadın Hastalıkları ve Doğum Anabilim Dalı, Turkey

Tel: +90 216 - 6254545 E-mail: drsunullah@yahoo.com

Ulus Travma Acil Cerrahi Derg 202I;27(I):73-78 DOI: 10.14744/tjtes.2020.25668 Submitted: 23.07.20I9 Accepted: 03.05.2020 Online: 10.12.2020

Copyright 2021 Turkish Association of Trauma and Emergency Surgery 
Pregnant women involved in traffic accidents should be managed according to maternal and fetal status. The management of a pregnant trauma patient warrants consideration of several issues specific to pregnancy, such as alterations in maternal physiology and anatomy, exposure to radiation and other possible teratogens, the need to assess fetal well-being, and conditions that are unique to a pregnancy and are related to trauma (Rh isoimmunization, placental abruption, and preterm labor). The majority of trauma cases during pregnancy are minor, and these have fewer risks than those that are major. ${ }^{[6,9,12]}$ Generally, hospitalization is recommended by the obstetrician for pregnant women involved in traffic accidents independently of the severity of trauma. This makes patients and relatives concerned about the health of both mother and fetus. Thus, we analyzed the records of pregnant women involved in traffic accidents to investigate their maternal and neonatal results according to several factors, including the severity of trauma and the necessity of hospitalization.

\section{MATERIALS AND METHODS}

This retrospective study was conducted in a tertiary center in the east of Istanbul, Turkey. The local ethical committee of the hospital approved this study (date: 04.01.2019, no: 09.2019.043). The sample was chosen from hard and soft copies of hospital records. Records of admissions to the hospital's Emergency Department between January 2012 and December 2018 were analyzed. In this study, 95 pregnant women involved in traffic accidents were included. In addition to patient demographics, the season in which the accident occurred, gestational weeks at admission, the time between accident and admission, and the method of transport to the hospital (car, taxi, walking, or ambulance) were noted. Patients' Glasgow Coma Scores were also recorded. The type of trauma (no visual trauma, superficial abrasions, abdominal trauma, fracture of the extremities, cranial trauma, or multiple traumas) and the obstetric result of the accident (no complication, start of labor, rupture of membranes, abortion, or placental abruption) were noted. Patients with multiple trauma and fractures were accepted as major trauma, remaining ones were classified as minor trauma. In addition, the recommendation for hospitalization, patient's acceptance of hospitalization, the use of urgent obstetric interventions, and the final health status of mother and fetus were recorded.

\section{Statistical Analyses}

Data analysis was performed using Statistical Package for the Social Sciences (SPSS) version 17.0. The Kolmogorov-Smirnov test and histogram graphics were used to analyze the normality of variable distributions. Descriptive statistics for numeric variables were defined as mean \pm standard deviation (SD), minimum and maximum values, and categorical variables were defined as number (n) and percent (\%). Relationships between nominal variables were analyzed using the Pearson Chi-square Tests. A p-value of $<0.05$ was considered statistically significant. Post hoc analysis was performed for trimester comparison and adjusted $p$-value of $<0.016$ was considered statistically significant.

\section{RESULTS}

In this study, 95 women who admitted to hospital due to traffic accidents between January 2012 and December 2018 were evaluated. Patients' mean age was 27.6 (I8-44, 5.9 SD) years. Mean gravida was 1.83 , parity was 0.63 , and abortion was 0.23 . The proportion of patients in each trimester was similar, with $29 \%$ in the first trimester, $38 \%$ in the second, and $33 \%$ in the third. Patients' mean gestational age was 21.5 weeks (4.I-38.6, SD 9.7), and their mean Glasgow Coma Score was 14.69 (3-15, SD 1.74; Table I). In this study, $18 \%$ of patients had a cesarean section in their obstetric history. In total, $73 \%$ of patients were involved in in-car accidents, while $27 \%$ were involved in a pedestrian versus motor vehicle accidents. Around half (57\%) of patients were transferred to the hospital within one hour of their accident, and $45 \%$ were transferred by ambulance. Just over half (59\%) of accidents occurred during spring and summer.

Seventy-one percent of patients had no visual traumas, and $58 \%$ required no consultations other than obstetrics. $\mathrm{Pa}-$ tients with multiple trauma six $(6.3 \%)$ and fracture I (I.I\%) were accepted as major trauma (7.4\%) and the remaining 88 patients $(92.6 \%)$ had minor trauma. Hospitalization was recommended for 50 patients, but $58 \%$ of these refused to be admitted. Overall, 89 of the patients (94\%) had no acute implications of the accident. Preterm labor was seen in three of patients (3.2\%), three of patients (3.2\%) experienced fetal

Table I. Demographics, obstetric features and Glasgow score

\begin{tabular}{lccccc}
\hline & Mean & Standard deviation & Median & Minimum & Maximum \\
\hline Age & 27.61 & 5.89 & 27.00 & 18.00 & 44.00 \\
Gravida & 1.83 & 1.17 & 1.00 & 1.00 & 6.00 \\
Parity & 0.63 & 1.01 & 0.00 & 0.00 & 5.00 \\
Abort & 0.23 & 0.54 & 0.00 & 0.00 & 2.00 \\
Gestational week & 21.53 & 9.76 & 22.30 & 4.10 & 38.60 \\
Glasgow score & 14.69 & 1.74 & 15.00 & 3.00 & 15.00 \\
\hline
\end{tabular}


loss, and five of patients (5.3\%) experienced placental abruption. There were no abortions. Urgent cesarean sections were performed on four patients, and no perimortem cesarean section was performed (Table 2). According to the results, $94 \%$ of pregnancies continued without complications. In one case, both the mother and fetus were lost. The mother was a 20-year-old patient at 34 weeks of gestation who experienced multiple traumas after being in a pedestrian versus motor vehicle accident. In total, three patients who delivered shortly after the accident were healthy, and in two cases, fetuses were lost due to placental abruption (Table 2).

The indication of hospitalization was evaluated by examining different variables. Hospitalization was indicated in $80 \%$ of patients in the third trimester, $58 \%$ of patients in the second trimester, and only $14 \%$ in the first trimester. There was a statistically significant difference among trimesters regarding the indication of hospitalization $(p<0.05)$. Post-hoc analysis between trimesters was performed regarding hospitalization. Hospitalization indication in the first trimester was low compared to second and third trimester separately ( $p$ for both $<0.00 \mathrm{I}$ ). There was no significant difference regarding hospitalization between the second and the third trimester $(p=0.049)$. The type of the accident, time of transfer, season of accident, and type of trauma showed no significant variation concerning whether or not hospitalization was indicated (Table 3). Overall, hospitalization was recommended for 50 patients, but $58 \%$ of these refused to be admitted. Of these, two $(7 \%)$ patients returned to hospital within the next 12 hours. None had any complications.

\section{DISCUSSION}

Since major trauma during pregnancy is associated with adverse maternal and neonatal outcomes, ${ }^{[2,3]}$ pregnant women

Table 2. Traffic accident features, hospitalization, and obstetric outcomes

\begin{tabular}{|c|c|c|c|c|c|}
\hline & Count & Column N \% & & Count & Column N \% \\
\hline Accident type & & & Abrasion & 17 & $(17.9)$ \\
\hline In-car & 69 & $(72.6)$ & Multiple trauma & 6 & (6.3) \\
\hline Pedestrian & 26 & $(27.4)$ & Hospitalization & & \\
\hline Admission time & & & Indicated & 50 & $(52.6)$ \\
\hline Within I h & 54 & $(56.8)$ & Not indicated & 45 & $(47.4)$ \\
\hline Between one and six $h$ & 35 & (36.9) & Obstetric implication & & \\
\hline More than six $\mathrm{h}$ & 6 & (6.3) & Not present & 89 & $(93.7)$ \\
\hline Admission type & & & Placental abruption & 5 & $(5.3)$ \\
\hline Ambulance & 43 & $(45.3)$ & Start of labor & I & $(\mathrm{I} .1)$ \\
\hline Own car & 31 & $(32.6)$ & Obstetric intervention & & \\
\hline Taxi & II & $(11.6)$ & Not present & 91 & $(95.8)$ \\
\hline Walking & 10 & $(10.5)$ & Urgent cesarean & 4 & $(4.2)$ \\
\hline Consultation & & & Response of patient to hospitalization & & \\
\hline Only obstetrics & 55 & $(57.9)$ & No recommendation & 45 & $(47.4)$ \\
\hline Neurosurgery & 5 & $(5.3)$ & Accepted & 21 & $(22.1)$ \\
\hline Orthopedics & 12 & $(12.6)$ & Rejected & 29 & $(30.5)$ \\
\hline General surgery & 1 & $(\mathrm{I} . \mathrm{I})$ & Intensive care unit needed for newborn & & \\
\hline Reconstructive surgery & 1 & $(1.1)$ & Needed & 3 & $(100.0)$ \\
\hline Multiple & 19 & $(20.0)$ & Not needed & 0 & $(0.0)$ \\
\hline Ear, nose \& throat & 2 & $(2.1)$ & Patients re-admitted after rejection & & \\
\hline Season of occurrence & & & of hospitalization & & \\
\hline Winter & 20 & $(2 I . I)$ & Not re-admitted & 27 & $(93.1)$ \\
\hline Spring & 26 & $(27.4)$ & Re-admitted & 2 & $(6.9)$ \\
\hline Summer & 30 & $(31.6)$ & Final result & & \\
\hline Fall & 19 & $(20.0)$ & No complications & 89 & $(93.6)$ \\
\hline Trauma type & & & Healthy mother and alive newborn & 3 & $(3.1)$ \\
\hline No visual trauma & 71 & $(74.7)$ & Fetal loss & 2 & $(2.1)$ \\
\hline Fracture & 1 & $(1.1)$ & Maternal and fetal loss & I & $(I .1)$ \\
\hline
\end{tabular}


Table 3. Effects of trimester and accident features on hospitalization

\begin{tabular}{|c|c|c|c|c|c|c|}
\hline & & \multicolumn{4}{|c|}{ Hospitalization } & \multirow[t]{3}{*}{$\mathbf{p}^{\prime}$} \\
\hline & & \multicolumn{2}{|c|}{ Not-Indicated } & \multicolumn{2}{|c|}{ Indicated } & \\
\hline & & $\mathbf{n}$ & $\%$ & $\mathbf{n}$ & $\%$ & \\
\hline \multirow[t]{3}{*}{ Trimester } & I & 24 & 85.7 & 4 & 14.3 & $<0.001$ \\
\hline & 2 & 15 & 41.7 & 21 & 58.3 & \\
\hline & 3 & 6 & 19.4 & 25 & 80.6 & \\
\hline \multirow[t]{2}{*}{ Accident type } & In-car & 32 & 46.4 & 37 & 53.6 & 0.753 \\
\hline & Pedestrian & 13 & 50.0 & 13 & 50.0 & \\
\hline \multirow[t]{3}{*}{ Admission time } & Within I h & 24 & 44.4 & 30 & 55.6 & 0.805 \\
\hline & Between I-6h & 18 & 51.4 & 17 & 48.6 & \\
\hline & More than $6 \mathrm{~h}$ & 3 & 50.0 & 3 & 50.0 & \\
\hline \multirow[t]{4}{*}{ Accident season } & Winter & 10 & 50.0 & 10 & 50.0 & 0.111 \\
\hline & Spring & 17 & 65.4 & 9 & 34.6 & \\
\hline & Summer & 10 & 33.3 & 20 & 66.7 & \\
\hline & Fall & 8 & 42.1 & 11 & 57.9 & \\
\hline \multirow[t]{4}{*}{ Trauma type } & No visual & 33 & 46.5 & 38 & 53.5 & 0.611 \\
\hline & Fracture & 1 & 100.0 & 0 & 0.0 & \\
\hline & Abrasion & 9 & 52.9 & 8 & 47.1 & \\
\hline & Multiple & 2 & 33.3 & 4 & 66.7 & \\
\hline
\end{tabular}

'Pearson Chi-Square.

involved in traffic accidents with major trauma should have a complete assessment and hospitalization for further observation and intervention. For evaluation of fetal well-being, all pregnant trauma patients with a viable pregnancy ( $\geq 23$ weeks) should undergo electronic fetal monitoring for at least four hours. Pregnant trauma patients ( $\geq 23$ weeks) with adverse factors, including uterine tenderness, significant abdominal pain, vaginal bleeding, sustained contractions (>I/10 min), rupture of the membranes, atypical or abnormal fetal heart rate pattern, or serum fibrinogen $<200 \mathrm{mg} / \mathrm{dL}$, should be admitted for observation for 24 hours. Anti-D immunoglobulin should be administered to all rhesus D-negative pregnant trauma patients. All pregnant trauma patients with a viable pregnancy who are admitted for fetal monitoring for greater than four hours should have an obstetrical ultrasound before discharge from the hospital. ${ }^{[14]}$

When the effects of severity of the trauma on pregnancy are questioned, studies on pregnant women with minor trauma generally suggest favorable outcomes. ${ }^{[3,8,15]}$ Thus, hospitalization for those cases is controversial. In the present study, pregnant women who were involved in traffic accidents with a minor trauma had favorable maternal and neonatal outcomes. These results are consistent with other studies dealing with all type of minor trauma cases during pregnancy. Pak et al. ${ }^{[8]}$ prospectively evaluated 85 pregnant minor trauma patients and found no correlation between the traumatic event and subsequent preterm labor. Cahill et al. ${ }^{[3]}$ studied 256 women who had sustained minor trauma during pregnancy at 23 weeks and six days of gestation and beyond. Among the different types of traumas included in the study, motor vehicle accidents comprised $29.4 \%$ of cases. In this study, only one patient had placental abruption. Favorable pregnancy outcome was also shown in a study where 512 pregnant women at 23 weeks or more who were admitted due to minor trauma $(34.3 \%$ of pregnant women had motor vehicle accident) were included. Preterm birth and placental abruption were seen in $5.9 \%$ and $1.2 \%$ of cases, respectively. ${ }^{[15]}$ Cheng et al. ${ }^{[16]}$ studied 8,762 minor, 6,076 major trauma cases during pregnancy. In contrast to favorable outcome results, Cheng's study revealed a higher preterm labor rate (odds ratio $=1.35$ ) in minor injuries.

In a large sample sized retrospective cohort study, 10,316 delivery patients who sustained different types of trauma during pregnancy were studied regarding maternal and fetal outcomes. Patients were grouped according to time of delivery. Maternal, fetal and neonatal outcomes of patients who delivered at the time of trauma hospitalization were significantly worse than patients who delivered in subsequent hospitalizations. Patients who delivered in subsequent hospitalization had worse outcomes compared with the control group but with a much less degree than patients who delivered at the time of trauma. ${ }^{[9]}$ 
Most of the studies related to trauma during pregnancy deal with every type of trauma. Few studies have analyzed traffic accidents alone. Vivian-Taylor et al. ${ }^{[17]}$ investigated 2147 car crashes between 2000 and 2007 and demonstrated that placental abruption was seen in $1.6 \%$ of patients with a perinatal death risk of $1.6 \%$. In our study, unfavorable outcomes were only seen in major trauma cases. In a large retrospective cohort study, Schiff et al. ${ }^{[10]}$ studied 625 pregnant women involved in motor vehicle crashes in which the majority of pregnant women in crashes were in their third trimester (65.9 percent). Of these women, 518 (82.9 percent) were hospitalized and subsequently discharged without delivering, and 107 (I7.I percent) delivered during their crash hospitalization. Significantly increased risk of preterm labor, placental abruption, and cesarean delivery was shown among pregnant women involved in motor vehicle crashes compared with women not involved in crashes. Stratifying their trauma analysis as severe and non-severe, they found that severely injured pregnant women had an increased risk of cesarean section and placental abruption compared with pregnant women not involved in motor vehicle crashes. In contrast to our findings, it was stated that pregnant women involved in crashes who had no documented injuries were at a marked increased risk of preterm labor and placental abruption and that their infants were at an increased risk of preterm delivery, low birth weight, and infant respiratory distress syndrome compared with pregnant women not involved in motor vehicle crashes.

Weiner et al. ${ }^{[18]}$ studied 946 pregnant patients $(25.8 \%$ involved in motor vehicle accidents) who were involved in minor trauma to investigate the necessity of hospitalization in this population. Sixty-five percent of women were hospitalized for 24-hour surveillance, and $35 \%$ of women refused to be hospitalized. No difference in preterm birth rate, vaginal bleeding, gestational age at delivery and cesarean delivery was shown between groups. It was concluded that pregnant patients with minor trauma who underwent normal initial assessment did not require hospitalization as our study reveals the same recommendation.

Studies conducted in Turkey related to trauma and pregnancy also reveal favorable outcomes. Üstünyurt et al. ${ }^{[19]}$ studied 173 pregnant women who had minor trauma. Of these, I8 (10.4\%) were involved in traffic accidents. No fetal loss and preterm labor was shown in early period after trauma. Karadaş et al. ${ }^{[20]}$ studied 139 pregnant trauma patients without classifying the trauma severity. In general, $95.7 \%$ of whole cases had no maternal and fetal complications. In the same study among 25 traffic accident cases, five (17\%) fetal and two $(7 \%)$ maternal losses were shown in contrast to general favorable result of the whole types of traumas.

In light of the increased risk of adverse maternal and perinatal outcomes resulting from major trauma, pregnant women who sustained major trauma requires hospitalization for maternal and fetal monitoring. Current literature reveals that pregnancy outcomes are affected by the trauma severity, gestational weeks during trauma and delivery occurrence during trauma hospitalization. Although major trauma and its effects on pregnancy are well defined, controversies are present regarding minor trauma cases.

\section{Conclusion}

Pregnant women who had minor trauma in traffic accidents with normal initial fetal and maternal findings have favorable pregnancy outcomes. Hospitalization requirement of pregnant women with minor trauma who sustained traffic accidents should be individually managed according to clinical presentation. Hospitalization for further observation of those patients is probably not necessary. Large prospective studies are needed for the definition of management of strategies for pregnant women with minor trauma in traffic accidents.

Ethics Committee Approval: Approved by the local ethics committee (date: 04.01.2019, no: 09.2019.043).

Peer-review: Internally peer-reviewed.

Authorship Contributions: Concept: S.S., D.S.; Design: S.S., D.S.; Supervision: A.D., T.P.; Resource: S.S.; Materials: M.Ç., A.T.T.; Data: S.S., M.Ç., A.T.T.; Analysis: S.S., D.S.; Literature search: S.S., D.S.; Writing: S.S., D.S.; Critical revision: A.D., T.P.

Conflict of Interest: None declared.

Financial Disclosure: The authors declared that this study has received no financial support.

\section{REFERENCES}

1. Karayolu Trafik Kaza İstatistikleri. Available from: http://www.tuik.gov. tr/PreHaberBultenleri.do?id=21611.

2. Hill CC, Pickinpaugh J. Trauma and surgical emergencies in the obstetric patient. Surgical Clinics of North America. 2008;88:421-40. [CrossRef]

3. Cahill AG, Bastek JA, Stamilio DM, Odibo AO, Stevens E, Macones GA. Minor trauma in pregnancy--is the evaluation unwarranted? American J Obstetrics and Gynecology 2008;198:208.e1-5. [CrossRef]

4. Mendez-Figueroa H, Dahlke JD, Vrees RA, Rouse DJ. Trauma in pregnancy: an updated systematic review. Am J Obstet Gynecol 2013;209:110. [CrossRef]

5. Redelmeier DA, May SC, Thiruchelvam D, Barrett JF. Pregnancy and the risk of a traffic crash. CMAJ 2014; 186: 742-50. [CrossRef]

6. Pearlman MD, Tintinalli JE, Lorenz RP. A prospective controlled study of outcome after trauma during pregnancy. Am J Obstet Gynecol 1990;162:1502-10. [CrossRef]

7. Schiff MA, Holt VL, Daling JR. Maternal and infant outcomes after injury during pregnancy in Washington State from 1989 to 1997. J Trauma 2002;53:939-45. [CrossRef]

8. Pak LL, Reece EA, Chan L. Is adverse pregnancy outcome predictable after blunt abdominal trauma?. Am J Obstet Gynecol 1998;179:1140-4.

9. El Kady D, Gilbert WM, Anderson J, Danielsen B, Towner D, Smith LH. Trauma during pregnancy: an analysis of maternal and fetal outcomes in a large population. Am J Obstet Gynecol 2004;190:1661-8.

10. Schiff MA, Holt VL. Pregnancy outcomes following hospitalization for motor vehicle crashes in Washington State from 1989 to 2001. Am J Ep- 
idemiol 2005;161:503-10. [CrossRef]

11. Weiss HB, Songer TJ, Fabio A. Fetal deaths related to maternal injury. Jama 2001;286:1863-8. [CrossRef]

12. Shah KH, Simons RK, Holbrook T, Fortlage D, Winchell RJ, Hoyt DB. Trauma in pregnancy: maternal and fetal outcomes. J Trauma 1998;45:83-6. [CrossRef]

13. Hirsh HL. Routine pregnancy testing: is it a standard of care? Southern Med J 1980;73:1365-6. [CrossRef]

14. Jain V, Chari R, Maslovitz S, Farine D, Bujold E, Gagnon R, et al. Guidelines for the Management of a Pregnant Trauma Patient. J Obstet Gynaecol Can 2015;37:553-74. [CrossRef]

15. Garmi G, Marjieh M, Salim R. Does minor trauma in pregnancy affect perinatal outcome?. Arch Gynecol Obstet 2014;290:635-41. [CrossRef]
16. Cheng HT, Wang YC, Lo HC, Su LT, Lin CH, Sung FC, et al. Trauma during pregnancy: a population-based analysis of maternal outcome. World J Surg 2012;36:2767-75. [CrossRef]

17. Vivian-Taylor J, Roberts CL, Chen JS, Ford JB. Motor vehicle accidents during pregnancy: a population-based study. BJOG 2012;119:499-503.

18. Weiner E, Gluck O, Levy M, Ram M, Divon M, Bar J, et al. Obstetric and neonatal outcome following minor trauma in pregnancy. Is hospitalization warranted? European J Obstet \& Gynecol Repro Bio 2016;203:78-81.

19. Üstünyurt E, Akaltun C. Minor Trauma in Pregnancy: Evaluation of 173 Cases. J Clin Analytical Med 2015;6:349-52. [CrossRef]

20. Karadaş S, Gönüllü H, Öncü MR, Kurdoğlu Z, Canbaz Y. Pregnancy and trauma: analysis of 139 cases. J Turkish German Gynecol Association 2012;13:118. [CrossRef]

\section{ORIJIINAL ÇALIŞMA - ÖZET}

\section{Trafik kazalarının gebelik üzerine etkisi: Her olguda hastaneye yatış gerekli midir?}

\section{Dr. Sunullah Soysal, ${ }^{1}$ Dr. Didem Soysal, ${ }^{1}$ Dr. Meral Çevik, ${ }^{1}$ Dr. Aslı Tuğçe Temurlenk, ${ }^{1}$}

Dr. Arzu Denizbaşı, ${ }^{2}$ Dr. Tanju Pekin ${ }^{1}$

${ }^{1}$ Marmara Üniversitesi İstanbul Pendik Eğitim ve Araştırma Hastanesi, Kadın Hastalıkları ve Doğum Anabilim Dalı, İstanbul

${ }^{2}$ Marmara Üniversitesi İstanbul Pendik Eğitim ve Araştırma Hastanesi, Acil Tıp Anabilim Dalı, İstanbul

AMAÇ: Bu çalışmada trafik kazası geçirmiş gebelerde hastaneye yatışın gerekli olup olmadığııı göstermek amaçlanmıştır.

GEREÇ VE YÖNTEM: İstanbul Türkiye'deki bir hastanede 2012 ve 2018 yılları arasında trafik kazası geçirmiş hastalar çalısılarak, gebe hastaların kayıtları incelendi. Hastaların demografik ve obstetrik özellikleri, kaza türü, travma çeşidi, Glasgow koma skoru, hastaneye yatış endikasyonu, hastanın hastaneye yatış önerisine yanıtı ve kazanın obstetrik ve maternal sonuçları değerlendirildi.

BULGULAR: Toplamda çalışmaya 95 hasta dahil oldu. Elli hastaya hastaneye yatış önerildi, bu hastaların \%58'i yatışı kabul etmedi. Yatışı kabul etmeyen hastaların hiçbirisinde komplikasyon gelişmedi. Hastaların yüzde 3.2'sinde preterm doğum, \%3.2 fetal kayıp ve \%5.3 plasenta dekolmanı görüldü. Bir anne (\%।.I) trafik kazası sonucu oluşan çoklu travma nedeniyle kaybedildi. Gebelik haftasının artışıla hastaneye yatış gerekliliği artarken, diğer parametrelerin hastaneye yatış üzerinde herhangi bir etkisi bulunmadı.

TARTIŞMA: Gebelik haftasının artmasıyla, trafik kazası geçirmiş gebelerin hastaneye yatış gereksinimleri artar. Hastaneyi yatışı kabul etmeyen minör travmalı gebelerde herhangi bir komplikasyon gelişmedi.

Anahtar sözcükler: Gebelik; hastaneye yatış; trafik kazaları.

Ulus Travma Acil Cerrahi Derg 2021;27(I):73-78 doi: 10.14744/tjtes.2020.25668 